\title{
Augustine and Monica in the Abbotsford Legenda Aurea
}

\author{
Alice E. Spencer \\ Università degli Studi di Torino
}

The following piece will represent the first in-depth evaluation of the lives of Saint Augustine and his mother Monica in the as-yet unpublished Abbotsford manuscript, Bokenham's long-lost translation of the Legenda Aurea, a text which survives in a single manuscript, purchased by Sir Walter Scott at Sotheby's in 1809, which had remained unattributed and unstudied until it was brought to the attention of Simon Horobin by the Faculty of Advocates in 2004 (Horobin 2008: 135). As a celebration of the remarkable piety of a wife and mother (as opposed to a virgin martyr), it is a highly unusual hagiographic text and would have presented a particularly accessible model of spirituality to the network of powerful lay female patrons by whom we know Bokenham to have been employed. I will argue that Bokenham's vita espouses an incarnational Augustinian poetics which is at odds with the more ascetic, eremitical vision of the original Legenda Aurea.

Keywords: Osbern Bokenham; Abbotsford Legenda Aurea; Augustine; Monica; hagiography

\section{Introduction}

The present article will represent the first extended analysis of the lives of Saint Augustine and his mother Monica in the as-yet unpublished Abbotsford manuscript, Bokenham's long-lost translation of the Legenda Aurea, a text which survives in a single manuscript, purchased by Sir Walter Scott at Sotheby's in 1809, which had remained unattributed and unstudied until it was brought to the attention of Simon Horobin by the Faculty of Advocates in 2004 (Horobin 2008: 135). These two lives have an especially important place within the collection, since we would expect Bokenham to have taken a particular interest in the life and works of the founder of his own order. The

Alice E. Spencer, Selim24 (2019): 135-148.

ISSN 1132-631X / DOI https://doi.org/10.17811/selim.24.2019.135-148 
life of Monica is remarkable inasmuch as it represents what appears to be the first medieval English life of the saint. As a celebration of the remarkable piety of a wife and mother (as opposed to a virgin martyr), it is a highly unusual hagiographic text and would have presented a particularly accessible model of spirituality to the network of powerful lay female patrons by whom we know Bokenham to have been employed. ${ }^{1}$

The primary source for Bokenham's life of St Augustine is Voragine's Legenda Aurea. However, he diverges from Voragine at several crucial junctures. Specifically, in the early parts of the legend, he draws from Jordanus of Saxony's De vita sancti augustini episcopi or, very possibly, directly from Capgrave's translation thereof. All of these insertions serve to expand on and foreground the role of Augustine's mother, Monica, in his spiritual journey an emphasis reflected in Bokenham's inclusion of the first Middle English Life of Saint Monica. Together with various other small additions which Bokenham makes to his source, these borrowings also serve to intensify and render more continuous the role of grace and providence in Augustine's narrative. At the very end of the text, instead, he translates from Possidius' Vita augustini. This closing passage, together with another brief adjustment which Bokenham makes to his source, serves to illustrate the continuity of the Augustinian monastic community with its saintly founder and, in so doing, to lend authority to the hagiographic text and its author. More broadly speaking, I will argue that Bokenham's vita espouses an incarnational Augustinian poetics which is at odds with the more ascetic, eremitical vision of the original Legenda Aurea.

The source for Bokenham's life of Saint Monica is less clear. One possibility might be the (much longer) life of St Monica preserved in the autograph manuscript of Jordanus' writings on Augustine, Bibliothèque de l'Arsenal MS-251, together with his De vita sancti Augustini episcopi, a text which, like Bokenham's vita, includes a description of Monica's wifely, motherly and spiritual virtues and her death, which is followed by an account

\footnotetext{
${ }^{1}$ We know from Bokenham's own "Prologues" that Dame Isabel Bouchier, sister of Richard Duke of York, commissioned the life of Saint Mary Magdalen, and that Elizabeth Vere, wife of the twelfth earl of Oxford, requested that of Elizabeth of Hungary. The legend of Saint Anne was written for Katherine Denstone, who was also the dedicatee of the legend of Saint Katherine, together with Katherine Howard. The life of Saint Agatha was dedicated to Agatha Flegge, wife of an Essex landowner (Delany 1998: 15-22, Horobin 2007: 941-942).
} 
of the translation of her body from Ostia to Rome. The account, written by Walterus of Arrouaise and included in the Acta santorum for 2 May, is a compilation of excerpts from the Confessions referring to Monica.

\section{Augustine, Monica and the ascetic ideal in Jacobus de Voragine's Legenda Aurea}

Bokenham's primary source throughout most of his Lyf of Seynt Austyn the Doctour is Jacobus de Voragine's Legenda Aurea - a text which, as Sherry L. Reames has demonstrated, presents us with a narrative of Augustine's conversion which would scarcely be recognizable to modern readers familiar with the troubled and reassuringly human scholar depicted in the Confessions. Voragine tends to idealise Augustine, omitting references to his sinfulness and recounting his boyhood sins only "to illustrate the great purity and humility of a soul that would bother to confess such trivial flaws" (Reames 1985: 136). As a consequence of this, the redemptive agency of Augustine's mother Monica is largely denied (ibid. 139, Winstead 2007: 194-195). Reames argues that the pivotal significance of Augustine's baptism is radically altered in Voragine's account. Whereas in the Confessiones Augustine's baptism occurs when he has finally overcome heresy and sin, in Voragine's version the moment of baptism marks a complete renunciation of the world -a contemptus mundi:

One can almost say that Augustine's earthly existence ends with conversion. (Reames 1985: 143)

What is missing from Jacobus' account of Augustine's spiritual journey is what Reames terms the "Incarnational pattern" of the Confessiones — the centrality of the humanity, humility and compassion of Christ to Augustine's original narrative:

One does not greatly oversimplify the Confessions by asserting that the remedies for all of Augustine's doubts and sins - and those of the human race he represents- are found in the Incarnation. Man's intellectual pride is vanquished by the humility of a Lord who embraced the condition of his creatures, flesh and all; man's fear of commitment, by the magnitude of the love that reaches down to him; the bondage of his habitual sins, by the liberty conferred on his will when he simply surrenders to Christ, confessing his total dependence on him and participating in his saving humility. (ibid. 139-140) 
By removing the intercessional agency of Monica and the compassionate grace of Christ from the narrative, Voragine introduces a radical binarism into his account of the saint's life which had little to do with the vision of Augustine himself and which left no space, for example, for the lay piety of Bokenham's patrons. I will argue that Bokenham's treatment of Monica and Augustine tends to reintroduce this "incarnational pattern" and, indeed, to locate therein the justification for the hagiographer's own output. Bokenham rests his own claims to literary authority on the inclusiveness of the communio sanctorum: on the redemptive force of the incarnation; on the saints' imitatio Christi; on the fraternity and continuity between Augustine and his monastic followers in the past and present; and on the parallels between the intermediary function of the saints and the intercessional function of hagiography itself.

\section{Bokenham's Lyf of Seynt Monica Seynt Austyns Modir}

The Abbotsford MS is remarkable in containing the first medieval English Life of Saint Monica (Abbotsford 101v-102r, Winstead 2011: 344). It is true that there was a proliferation of hagiography dealing with female saints in the fifteenth century, but Saint Monica stands apart from these other subjects in being neither a virgin nor a martyr but rather a wife and mother. Winstead has shown us that fifteenth-century virgin martyr legends have a tendency to underline the humanity and exemplarity of the saints, presenting them, as much as possible, as appropriate models of female piety for contemporary English gentlewomen (Winstead 1997). However, as a pious, assertive married mother Monica's experience came far closer to that of Bokenham's East Anglian female patrons than that of any of these saints. As well as being remarkable in her religious devotion, Monica is also held up (following Book IX of the Confessiones) as an exemplary wife and mother, prudently and patiently managing her errant son and a recalcitrant, abusive and unfaithful husband and a difficult, live-in mother in law (fol. 101r). In stark contrast to Voragine's binarism and contemptus mundi, Bokenham presents Monica as harmoniously combining mundane and spiritual values.

The Lyf of Seynt Monica Seynt Austyns Modir is noteworthy in the extent to which it foregrounds Monica's agency in her son's salvation. Indeed, Bokenham places her at an equal standing with Simplicianus, claiming that: 
thurgh the merite of hir preyers and the prechyng and the hooly exortacions of seynt Symplician hir sone was convertid and made a perfite cristen man. (fol. $102 \mathrm{v})$

Monica is extolled and endorsed by Augustine and Ambrose as an authority in matters of divinity. Rather extraordinarily, her "natural witte enflamed with natural wisdam" is placed on a par with, if not even above, masculine clerical learning and authority:

This blissid woman loued excellently wele the holy bysshop Seynt Ambrose for as moche as he was cause of the gostely helthe of Austyn hir sone and he therageyn lovid hyr singularly for hir hooly and religious conuersacion and for she was feruent in sprite in gode werkis and for noon houre she left withoute preyer and preysyng of god gretely reioyssing that he sawe such a modir of such a sone. And of hir natural witte enflamed with natural wisdam thurgh the special grace of god spekyng hir sone in Sentence seith on this wise in disputacion of a not little thing but of a right grete thing the which I remembrid me and put it into a boke so gret and so excellent hir reson and hir wytte apperid unto me that aftir my felyng and myn undirstondyng no thing might more ably and more conuently ben alluded and [...] to very and true philosophie. Wherfore quoth he fro thens forward I provided and ordeyned that whan leyser and oportunyte habounded that ony thing of diuinite shuld be dysputid that she shuld nat ben absent so grete excellence of witte and reson I fonde in hir comunyng. (fol. 102r)

In general, Monica's devotion is characterized by an affective piety -an emotional, loving intimacy with God, strongly rooted in compassion for Christ incarnate: she is described as being "fastenyd and nailed on the crosse with criste" and as having "contynnelly the passion of criste in hir mynde" (ibid.). Any suggestion that a clear dichotomy really existed between "feminine" affective and "masculine" intellectual and speculative forms of spirituality has been undermined by the work of scholars such as Bernard McGinn (1994) and Amy Hollywood (1995). However, it is also true that religious writers tended to characterize one kind of piety as "feminine" and another as "masculine" and that the model of "feminine" affective piety, although not without its dangers and controversies, at least evaded the rocky ground of female scriptural study and erudition. This characterization of Monica is consistent with her depiction in the Confessiones, where her example plays such a crucial role in undermining Augustine's devotion to philosophy and his intellectual pride (Power 1996: 
71-93). However, as Laferrière argues, these elements had been largely eliminated from medieval Augustinian accounts of the story, where,

by omitting her character, the authors were able to gloss over troublesome episodes of Augustine's faith wavering and examples of a woman surpassing their founder in religious excellence. (Laferrière 2017: 73)

In Bokenham's account, as in Capgrave's, we find that she has been thoroughly reinstated. Her relationship with the divine seems, in its immediacy and simplicity, to be privileged over that of her son, as witness Bokenham's inclusion and treatment of the following miracle narrative:

the seid hand maiden of criste shuld receiven the sacrament of cristis precious body she was so rapt with the spirite of compunccion and devocion that she was seen lyfted up a cubite from the erthe and notwithstondyng that she was wone to be moste quyete cried moste swetely and seid fflye we to heven flye we to heven with which crie she replenisshid and fulfilled Austyn hir sone and al the meynee of hir housholde with an inestimable ioye and gladnesse seeing the grete grace of compunccyon and of devocion that god had shewid in hir. (fol. 101r)

Bokenham's life of Monica also contains an extended description of the mystical experience which Augustine shares with Monica at Ostia shortly before her death (fol. 102v). This episode, which is of central importance in the Confessions and is also described in the vitae of Augustine by Jordanus of Saxony and Capgrave, was omitted in the Legenda Aurea and, as Anik Laferrière has noted, had tended to be left out of Augustinian accounts of the saint's life (Laferrière 2017: 79):

And whan that Austyn hir sone was conuertid and baptized and made a parfite christen man and he and she with many other returning ageyn to Affrik weren at Hostye abiding [...] it happid hem tweyn to stonden togider alone at a wyndowe comonyng and talkyng of the evirlastyng life of seyntis in heven the which neither eigh hath seyn nor eer herd ner hert fully thoght. In whiche communicacioun the worlde with alle the delectaciouns therof was so little apprised and sette by in hir affeccion an so lithesome and so tedious to hir that at the last sche brak oute with these wordis and seid Siker Sone what I shuld lenger doon here o why I am here now I wote for fully al the hope of this werld is to live in contempt and in despite. Oo thing oonly ther was for which I desired to taryen and abiden here a while that is that I myth er than I passed 
hens seen the sone a parfite christen man. And God of his inestimable grace hath parfourmid my desire more plenteously than I askid it. (fol. 102r)

The authoritative voice here, transcending earthly desires, is that of Monica, not of her famous son.

\title{
4. Sons and brothers: Augustinian agency, intercession and the translation of Monica
}

In the lines immediately following this passage, in Bokenham's account of Monica's final illness and death, the narrative voice makes an abrupt and somewhat disorienting shift into the first person voice of Book IX of the Confessiones. There is no precedent for this in the accounts of Monica's death in Jordanus, Capgrave or Voragine:

\begin{abstract}
Aftir whiche tyme five dayes she langired in the accesse so grevously labored that she sempt to ben alienat som what from her wittis. But sone aftir whan she came ageyn to hir self and bihelde me and my brethren stondyng abouten hir astonyed with morning and hevynesse she seyd thus to me and to my brother. Putteth here to sepulture your modir the which sone shal deyen. And at that worde quoth Austyn whan I gan mornen and wepyn my brother seid that he wolde nat that she shuld deyen there in her pilgrimage but rather goon hoom and be buryed in hir owen cuntre. Which worde she heryng turned hir eyen with an hevy chier to hymward first and afterward to me and seid see what he seith. And aftir that she spake to us both to gider and seid puttyth this body where so evir you list lattith no body be troubled with busynesse therefore but this oonly I prey you that where so evir ye ben whan ye stoned at goddis awtier than hath mynde upon me. (fol. 102r)
\end{abstract}

The "quoth Austin", which indicates that the first person narrative is a quotation, appears rather late on in the narrative and I would argue that it is not over-speculative to posit that Bokenham is here on some level identifying with the emotions and love of Augustine and his brothers - asserting the ties between the fraternity of Austin friars, their founder and the "mother" of their order (Holgate 2003).

At the end of his life of Saint Monica, Bokenham describes the translation of her physical remains from Ostia to the Church of Saint Trifone in Rome in April 1430: 
But as it plesid our lordis mercy the yere of grace a thousand foure hundred and thritty upon Palme Sunday that yere fallyng on the ninth day of April by Pope Martyn the fifte at the instaunce of his confessour and sexteyn of his chapel ffrere Peter Bysshop a frere Austyn and of frere Austyn of Rome that tyme priour general of the same ordre. She was translated to Rome solemnly and leid in the churche which Egidius de Roma made in the honour and wership of hir sone Seynt Austyn beside Seynt Triphones undir attestacion and certificacioun of many and grete myraclis shewid there that tyme the which were now to longe to written. (fol. 102r)

The agency of the Augustinian order is at the fore here and I would argue that, as elsewhere in Bokenham's oeuvre and most specifically in his depiction of the translation of Saint Margaret, parallels can be drawn between this act of translation and that being undertaken by Bokenham himself - between the translation of saintly corpse and hagiographical corpus (cf. Spencer 2013: 109-114). The naming of a famous Augustinian author, Giles of Rome, as the founder of the Church of Saint Trifone further enhances this connection, ultimately, I would argue, drawing connections between the hagiographical vita and the reliquary as vehicles of saintly authority. The Vita closes with a prayer for intercession:

Pray we now then finally al to our lorde god that for the merites and preyeris of blissid Monic he vouchsafe to senden us nat richessis ner worshippis ner no such fluwible thyngis that comen and goon withoute stabilnesse which she despised of al hir hert but that such thyngis mote fallen unto us that mow makyn us souereyn gode and souereyn blissid and that the wille of god may be so parfounmed in this world in us that in the tothir worlde we mow duellyn with hir and hir sone in evirlastyng blisse amen. (fol. 102r)

Bokenham here further reinforces the theme of Augustinian fraternity by asking Monica to intercede for Augustine's brothers in the same manner as she did for her son. He also, implicitly, adopts a parallel intercessional role for himself, acting as an intermediary between his patron and the saint in the same way that the saint should act as a go-between between the supplicant and God. 


\section{Monica in the Lyf of Seynt Austin the Doctour}

Bokenham's additions to the Legenda Aurea version of the life of Saint Augustine repeatedly serve to re-establish Monica's essential role in the narrative. Monica's piety is emphasized from the outset. Thus, while the opening of the Legenda Aurea simply names Augustine's parents, without providing any further deails (“[...] scilicet patre Patricio, matre Moniacha genitus", Graesse 1850: 549; "And his father was named Patricius and his mother Monica”, Granger-Ryan 1997: II.124), Bokenham mentions Monica's Christianity right away:

whos fadyr hyht Patrick a hethene man til the yer byforn that he deyis. Hys modrys name was Monica a cristene woman and an holy. (fol. 107v)

Whereas Voragine seems to deny Augustine's family any role in his education, Bokenham tells us that during his early life, he was "virtuously educat $[\ldots]$ at hoom" (ibid.). In an episode omitted from Voragine's vita, Bokenham borrows from Jordanus of Saxony's account of Augustine's life in detailing Monica's first struggles to get Augustine baptized:

This seyid Austyn oo tyme why he was yung was gretly and greuously vexed in hys stomack. Wherfore his modyr dredynge hys deth counseld hym for to byn cristenyd but his fadyr whiche that tyme was hethene wolde not sufferyn yt. And so for a tyme his baptem was dilayid. In whiche mene tyme by helpe of grace hys peyne secyd and he was hool. And [...] his puryficacioun by baptem was deferid for as moche as if he lyuyd he shulde nedys be defoulyd more yet and his offence shulde be the more greuous yf he synnyd aftyr hys baptem. (fol.

170v)

This reference to divine providence in response to Monica's prayers, together with the depiction of Monica's privileged relationship with God in the Lyf of Seynt Monica Seynt Austyns Modir, is indicative of another noticeable contrast between Bokenham and Voragine, who tends, instead, to "increase the remoteness of God" to the extent that

God is no longer a part of [Monica's] experience, as Jacobus relates it. (Reames 1985: 139)

When Monica follows her son to Milan, Voragine simply writes: 
Mater autem ejus quiescere non valens cum multa difficultate ad eum venit. (Graesse 1890: 550)

His mother, however, could not rest and, overcoming all sorts of difficulties, came to join him. (Granger-Ryan 1997: II.124)

Bokenham instead adds that she travelled "both on lond and watyr" recalling the descriptions in Jordanus and Capgrave ("[...] his modir, took pe se and put hirselue to gret perel for to se hir son [...] Sche is come to lond and to pe speche ofhir son", Smetana 2001: 30).

Bokenham describes Monica's love and admiration for Ambrose: "And seynt Ambrose she louyd as an aungel of god", fol. 170v). He thereby echoes Capgrave ("Sche loued Ambrose as an aungel of God", Smetana 2001: 30) and Jordanus ("sicut angelum dei", ibid. 83). Voragine, in contrast, makes no reference to any kind of relationship or interaction between the two, stressing, instead, only Augustine's immediate fascination with Ambrose's preaching.

\section{The miracle at Fonteine and monastic fraternity}

One of the various miracles narrated at the end of Jacobus' vita takes place at the Augustinian monastery at Fonteine in Burgundy. The Legenda Aurea account is as follows:

Apud Burgundiam in monasterio, quod dicitur Fontanetum, erat quidam monachus, Hugo nomine, sancto Augustino valde devotus, qui in ejus scriptis miro desiderio pascebatur, quem etiam crebra supplicatione rogaverat, ut ipsum ex hae luce migrare non sineret, nisi in die suae sacratissimae sollemnitatis. Ipse igitur XV die ante festum ejusdem sic coepit duris febribus aestuare, ut in vigilia ipsius super humum tamquam moriens poneretur. Et ecce plures decori ac fulgentes viri amicti albius ecclesiam dicti monasterii processionaliter intraverunt, quos sequebatur quidam reverendus pontificalibus insignitus. Quidam autem monachus in ecclesia consistens hoc videns obstupuit et, quinam essent vel quo pergerent, inquisivit. Cui unus corum dixit, quod sanctus Augustinus esset cum suis canonicis, qui ad devotum suum morientem pergeret, ut ejus animam ad regnum gloriae deportaret. Post hoc illa reverenda processio ad infirmarium ingreditur; ubi cum aliquamdiu manisset, sancta illa anima a carne soluta est, quam dulcis amicus et ab hostium insidiis securam reddidit et ad coeli gaudia introduxit. (Graesse 1890: 563) 
In the monastery of Fontaines at Burgundy there was a monk who was particularly devoted to Saint Augustine, read his writings zealously, and derived spiritual nourishment from them. For a long time he had petitioned the saint not to let him leave this life except on the day when his sacred feast was celebrated. Then, two weeks before the saint's feast day, the monk was stricken with a high fever and on the vigil of the feast was laid out on the ground to await death. And behold, a number of men, decorous and splendid in appearance and wearing white garments, entered the church in procession, followed by a venerable man clothed in pontifical vestements. A monk who was in the church was astounded at the sight of the procession, and asked the marchers who they were and where they were going. One of them said that Saint Augustine, with his canons, was on his way to his dying devotee to take his soul to the kingdom of glory. Then the solemn procession entered the infirmary, and after some time the monk's soul was released from his body, and his dear friend, shielding it from the grasp of the enemy, led it into the joy of heaven. (Granger-Ryan 1997: II.129)

Bokenham makes a slight but significant alteration in his version, converting the dialogue between the monastic onlooker and the canon into direct discourse and having the canon address the Austin friar as "brother":

Sykyr brother quoth he this ys seynt Austyn the grete doctor the whiche comyth with his bretheryn to visityn his deuote seruauntand to ledyn with hym his soule in to the blysse of heuene. (fol. $173 \mathrm{v}$ )

This stress on fraternity within the Augustinian order implicitly serves to underline the ties between the monastic hagiographer and his saintly subject, elevating his status and lending authority to his narrative.

\section{7. "Vox tua nempe mia est": The incarnational poetics of hagiography}

At the end of the vita, Bokenham abandons Voragine altogether and turns to Possidius, Augustine's first biographer, for a particularly striking statement of monastic fraternity and hagiographical auctoritas:

To makyn an ende thane of this blyssid and hooly mannys lyf seynt Austyn I concludyd with Possidane the whiche was a dyssiple of his longe conusaunce wiche in hys laste dayis and aftyr his deth compilid hys lyf as he saw and 
knewe. This seyid Possidone in ende of hys legend aftyr that he hath told how blyssyd austyn maad noo testament for bodily [...] he concludyth hym to hau lefth aftyr hym myche goostly rychesse for he leffte quoth he sufficient of lerge monasteries full stuffyd bothe of men and of women instruct with maners and arayid with bokys the whiche he had endityd hym self. Wherin he lyuyth to us thogh that in flesshe he be deed fro us. I seye that he leuyth to god and eek to us to god he lyuyth parfytely ioyned to hym by perpetual and inseparable fruycyoun. To us le lyuyth he lyuyth by his wrytyng dayle spekynge to us after the maner of spekynge of a poete the whiche de syttyu these vers up on hyre graue "Vivere post obitum vate vis nosse, viator? Quod legis ecce loquor: vox tua nempe mia est." Swich a man thanne quod Possidonie and so wurthi a fadyr and soo profund a doctor mote alle cristene people wurshipyn bothe religious and clerkys ffor bothe his doctrine ys instructyoun of alle feythfull men and the singular myrour of oure religioun. Be yt therefore dowtyd to no man that he is reseyryd in to the felaschepe of aungeles. Where he byholdyth the begynnyng of the vertu of god in the brythnesse of seyntys neuere with owte remembraunce and mynde of his brethryn but fully as I hope and presume he shall byn a medyatour to reformyn hem to god hic Possidoun. (fol. 174r)

This passage directly identifies the Augustinian monastic order as the spiritual heirs (the embodiment of the "goostly richesse") of Augustine. The Latin motto on Augustine's tomb $\mathrm{m}^{2}$ constitutes a particularly bold exaltation of the monastic hagiographer's voice and textual output. As Bokenham transmits Augustine's acts and teachings, his voice is appropriated by and identified with the saint. Just as the saint figures forth and acts as an intermediary with Christ, Bokenham transmits and mediates with the saints of whom he writes. Perhaps most intriguingly of all this intersection between a literary text (the poem) and the tomb of the saint implicitly raises the status of the hagiographical vita, which acquires the role of a reliquary, a vessel for the saint.

\footnotetext{
2 The motto might be roughly translated as follows: "Traveller, do you know that poets live beyond their death? What you read, behold, I speak, for your voice is truly my own."
} 


\section{Conclusions}

In conclusion, Bokenham rejects the ascetic binarism evident in Voragine's treatment of Augustine in favour of a renewed assertion of what Reames terms the "incarnational patterns" of the Confessiones. If Jacobus' saints exist at a far remove from temporal, mundane life, Bokenham instead grounds his retellings in a vision of sanctity which is characterized by community and continuity. His reinstatement of Monica as an active protagonist in her son's salvation serves to promote and endorse a model of feminine lay piety which would have been accessible and attractive to his female patrons. Monica's intercessional role is shared by the hagiographer himself, who documents saintly vitae and prays on behalf of his patrons. The sanctity of Monica as mother and Augustine as father/brother lend authority, cohesion and continuity to the monastic community of Austin friars, whose agency and status are repeatedly emphasized in the Abbotsford lives. Bokenham's treatment of the translation of Monica and of the verse on the tomb of Augustine serve in particular to invest the hagiographical text with something of the prestige of the reliquary, inasmuch as it becomes an enduring vessel for saintly authority.

\section{References}

\section{Primary Sources}

Advocates Library, Abbbotsford MS

British Library, Arundel 327 MS

Bibliothèque de l'Arsenale, MS-251

\section{Secondary Sources}

Bollandus, J. 1863: Acta Sanctorum. Paris and Rome: Bibliopolam.

Brown, P. 1982: The Cult of the Saints: Its Rise and Function in Latin Christianity. Chicago, University of Chicago Press.

Delany, S. 1998: Impolitic Bodies. Poetry, Saints and Society in Fifteenth Century England: The Work of Osbern Bokenham. Oxford, Oxford University Press.

Graesse, T. 1890: Jacobi a Voragine. Legenda Aurea: Vulgo Historia Lombardica Dicta. Breslau: Koebner.

Granger-Ryan, W. 1997: Jacobus de Voragine. The Golden Legend: Readings on the Saints. 2 vols. Princeton (NJ), Princeton University Press.

Hammond, C. J. B. ed. 2014: Augustine. Confessions. 2 vols. Cambridge (MA), Loeb Classical Library, Harvard University Press. 
Heffernan, T. 1992: Sacred Biography: Saints and their Biographers in the Middle Ages. Oxford, Oxford University Press.

Holgate, I. 2003: The Cult of Saint Monica in Quattrocento Italy: Her Place in Augustinian Iconography, Devotion and Legend. Papers of the British School at Rome 71: 181-206.

Hollywood, A. 1995: The Soul as Virgin Wife: Mechthild of Magdeburg, Marguerite Porete, and Meister Eckhart. Notre Dame (IN), University of Notre Dame Press.

Horobin, S. 2007: Politics, Poetry and Patronage in the Works of Osbern Bokenham. Speculum 82: 932-949.

Horobin, S. 2008: A Manuscript Found in the Library of Abbotsford House and the Lost Legendary of Osbern Bokenham. English Manuscript Studies 1100-1700 14: 130-164.

Laferrière, A. 2016: The Doubting Augustine: the Deletion of Monica from Fourteenth Century Vitae Augustini in the Augustinian Order of Hermits. Studies in Church History 52: 150-163.

Laferrière, A. 2017: The Austin Friars in Pre-Reformation England. (D.Phil. Thesis.) Oxford, Oxford University.

McGinn, B. 1994: Meister Eckhart and the Beguine Mystics: Hadewijch of Brabant, Mechtbild of Magdeburg, and Marguerite Porete. New York, Continuum.

Reames, S. L. 1985: The Legenda Aurea: A Re-Examination of its Paradoxical History. Wisconsin, The University of Wisconsin Press.

Sanok, C. 2007: Her Life Historical: Exemplarity and Female Saints' Lives in Late Medieval England. Pennsylvania, University of Pennsylvania Press.

Serjeantson, M. S. 1938: Osbern Bokenham. Legendys of Hooly Wummen (E. E. T. S. O.S. 206). London, Oxford University Press.

Smetana, C. L. 2001: Life of Saint Augustine by John Capgrave (edited from British Library Additional MS 36704 together with Jordanus of Saxony's Vita S. Augustine from Bibliothèque de l'Arsenale MS-251). Toronto, Pontifical Institute of Medieval Studies.

Spencer, A. 2013: Language, Lineage and Location in the Works of Osbern Bokenham. Newcastle-upon-Tyne, Cambridge Scholars Press.

Winstead, K. 1997: Virgin Martyrs: Legends of Sainthood in Late Medieval England. New York, Cornell University Press.

Winstead, K. 2006: John Capgrave's Fifteenth Century. Pennsylvania, University of Pennsylvania Press.

\author{
Author's address \\ Centro Linguistico di Ateneo \\ Università degli Studi di Torino \\ Via S. Ottavio, 20 \\ 10124 Torino, Italy \\ e-mail: alice.spencer@unito.it
}

received: 18 January 2019 revised version accepted: 29 March 2019 